\title{
MODELING THE BEHAVIOUR OF CHEMICAL RESISTANT CONCRETE MODIFIED WITH FLY ASH UNDER DIFFERENT PH ENVIRONMENTS
}

\author{
RAZ RIZGAR HAYDAR ${ }^{1 *}$, and AHMED SALIH MOHAMMED ** \\ * Dept. of Construction Engineering, Engineering, American University of Iraq, Sulaimani, \\ Kurdistan Region-Iraq \\ ** Dept. of Engineering, American University of Iraq, Sulaimani, Region-Iraq
}

(Accepted for Publication: December 8, 2020)

\begin{abstract}
Concrete is the main building unit used in infrastructure and buildings, including dams, swages, and sewage pipes. The main problem in the concrete used in the sewerage pipe or the water treatment system is the erosion when concrete becomes subjected to different pHs. This study's objective is to evaluate and model the effects of various $\mathrm{pHs}$ on plain concrete and concrete modified with fly ash. Water to cement ratio and time of curing were taken as independent variables in the experiment. The main dependent variables are the strengths of compression and tensile of the concrete. From the over 900 data collected, the w/c was ranged between 0.3-0.5. The compression strength varied from 0-88.6 MPa and tensile strength ranged from 0.5-5 MPa. Direct correlations between compression strength and w/c, curing time, pH value and fly ash precentage were not found. From the Nonlinear Model ( NLM) parameters, fly ash percentage has a positive effect on the concrete resisting the different $\mathrm{pH}$ values. However, FA\% content should not exceed $25 \%$ because it will cause the cement to lose its bonding qualities. FA might reduce the rate of penetration of the chemicals and make the concrete resist the chemicals to penetrate further into the interior of the concrete.
\end{abstract}

KEYWORDS: Concrete; pH; fly ash; chemical resistant; erosion

\section{INTRODUCTION}

C oncrete has been one of the main components in buildings and constructions for centuries. Concrete's mechanical properties, high compression strength, durability, high stiffness, cost-efficient and easily manufactured and fabricated, make it the perfect medium for constructing (Burhan, 2019 , p. 1). Over the years, concrete has seen development in its composition depending on its application and use. Depending on the concrete's strength, weight, thermal capacity or chemical resistance, concrete has different mixes that are designed for use ( $\mathrm{Li}, 2018$, p. 23-24). Typically, concrete is a mixture that is heterogeneous of cementation materials, , fine aggregate, gravel, rocks, coarse aggregate, sand, and water in the mixing hydration part or/ and curing part, and admixtures (Sathawanea, 2013, p. 36). Concrete has an isolation property making it durable toward fire, pollution, sunlight, and dust.

Normal concrete is a mix of cement, water, fine and coarse aggregate, and it has an average compressive strength of $25 \mathrm{MPa}$ but can reach
40 or $50 \mathrm{MPa}$ (Qadir, 2019, p. 1). In modern research, it was found that cement and producing cement is polluting the environment with massive $\mathrm{CO}^{2}$ production and pollution that it courses during manufacturing (Oner, 2007, p. 505). Therefore, other cementation materials such as fly ash are substituting the cement not only to reduce the cement usage for less ecological harm but also to improve its properties such as mechanical properties, durability, and hydration (Huang, 2013, p. 71).

The mixing of cement and fly ash will cause a pozzolanic reaction by binding free silica and $\mathrm{Ca}(\mathrm{OH})^{2}$ (Aydın, 2007, p. 717). The most utilized waste material of coal combustion products is fly ash due to its benefits. Fly ash has a high aluminous and siliceous content (Kaniraj, 2003 , p. 539). Fly ash has a higher percentage of $\mathrm{SO}^{-2}$ which makes the concrete be hydrated with less water to cement or water to binder ratio (Torii, 1994, p. 362). Many studies show that the controlled adding of FA for substituting cement will increase the compression strength of the concrete (Kumar, 2000, p. 347). Tensile strength increases with the addition of FA to the concrete

rr14322@auis.edu.krd, ahmed.salih@auis.edu.krd

${ }^{1}$ Corresponding author: Engineering Department, American University of Iraq, Sulaimani, Sulaimani - Kirkuk Rd, Sulaimania 
(Atis, 2004, p. 1117). Also, the most expensive material in concrete production is cement, and FA is a waste and recycled material, therefore using FA will reduce the cost. Using fly ash is an environmental benefit as well. The active hydration level will make the concrete early age and improves the workability as well.

Concrete is used in many applications, and it is exposed to a lot of environmental factors, such as high heat, freezing and thawing and aggressive chemicals. The concrete will be weaker and less durable due to these factors, so additives and new mix designs are added to make the concrete resist these harsh environments. Fly ash in concrete has shown that it reduces the voids of the concrete and decreases the external materials such as the wastewater, acids, and harmful materials to penetration into it (Chalee, 2010, p. 1242). Therefore, when there is a chemical attack on the concrete from swages wastewater or chemical wastes, the concrete that contains fly ash theoretically will have less damage than concrete not containing fly ash because the fly ash will modify the chemical composition of the concrete, which will lead the reduction the voids and micro-cracks, increase the bond of the materials, and reduce the disintegration $(\mathrm{Li}$, 2018, p. 24). In this review, data from 33 papers have been reviewed and collected to study the concrete's tensile and compression strength with many percentages of fly ash and being subjected to many $\mathrm{pH}$ values, from neutral 7 to nearly 0 and 14 , extreme $\mathrm{pH}$ values. The curing time was up to 28 days. Throughout 16 countries various percentages of FA were used to test the true effect of FA on concretes properties.

The study aims to study the compression and tensile strength of concrete with FA from 990 literature data. The first objective is water to cement ratio, fly ash content, curing time, $\mathrm{pH}$ exposer, compressive strength, and tensile strength statistical difference. The second is the effects of the independent variables which are: the water to cement ratio, time of curing, FA content, and curing $\mathrm{pH}$ on the dependent variables, compressive strength, and tensile strength by utilizing NLM. The final objective is to relate between the compressive strength and tensile strength.

\section{MATERIALS \& METHODS \\ 2.1Collection of data}

The mechanical behavior, compressive strength, and tensile strength, of concrete with FA cured in different $\mathrm{pH}$ values were the main focus of this study. Table 1 displays the plain concrete and modified concrete properties.

Table (1): Literature's concrete properties modified with fly ash

\begin{tabular}{|c|c|c|c|c|c|c|}
\hline Ref & Country & $F A \%$ & W/C & $\begin{array}{l}\text { Time of curing, } t \\
\text { (days) }\end{array}$ & $\begin{array}{c}\text { Comp strength, } \sigma c \\
(\mathrm{MPa})\end{array}$ & $\begin{array}{c}\text { Tens strength, ot } \\
(\mathrm{MPa})\end{array}$ \\
\hline 1 & Malaysia & $0-100$ & $0.4-0.59$ & 28 & $21-29$ & - \\
\hline 2 & Turkey & $0-70$ & $0.28-0.34$ & $1,3,7,28$ & $1.76-66.55$ & $1.81-4.2$ \\
\hline 3 & Turkey & $0-70$ & 0.4 & $1,3,7,28$ & 4.3-58.5 & $2.5-4.5$ \\
\hline 4 & Australia & $0-60$ & 0.35 & $7,14,28$ & $18.07-35.37$ & - \\
\hline 5 & $\begin{array}{l}\text { China and } \\
\text { Lithuania }\end{array}$ & 0 & 0.33 & 7,28 & $22.3-48.6$ & - \\
\hline 6 & Hong Kong & $0-35$ & $0.45-0.55$ & $1,4,7,28$ & $5.9-66.8$ & $0.49-3.43$ \\
\hline 7 & Germany & $0-25$ & 0.5 & 28 & - & 4.1-5 \\
\hline 8 & Japan & 0 & $0.4-0.58$ & $7,14,28$ & $24-62.1$ & - \\
\hline 9 & Iran & $0-20$ & 0.3675 & 7,28 & $21.6-36.34$ & 2.3-3.35 \\
\hline 10 & Turkey & 0 & $0.6-1.2$ & $7,14,28$ & $9.2-40.4$ & - \\
\hline 11 & India & 0 & 0.45 & 28 & 23.53-27.83 & $2.37-3.43$ \\
\hline 12 & Portugal & 0 & $0.4-0.57$ & 7,28 & 29.5-65.4 & - \\
\hline 13 & India & $0-30$ & 0.44 & $7,14,28$ & $32.89-45.78$ & 4.1-4.38 \\
\hline 14 & Australia & $0-60$ & 0.4075 & $3,7,28$ & $4-27.5$ & - \\
\hline 15 & India & $15-35$ & $0.41-0.44$ & 7,28 & $22.78-35.19$ & $1.55-2.4$ \\
\hline 16 & Australia & 18.3 & 0.35 & $1,7,28$ & $40-62$ & - \\
\hline 17 & India & $62-67$ & $0.4-0.6$ & 28 & 31.7-46.02 & - \\
\hline 18 & Canada & 0 & 0.4 & $1,3,7,28$ & $20.9-36.4$ & 2.7 \\
\hline
\end{tabular}

rr14322@auis.edu.krd, ahmed.salih@auis.edu.krd

${ }^{1}$ Corresponding author: Engineering Department, American University of Iraq, Sulaimani, Sulaimani - Kirkuk 
Journal of University of Duhok, Vol. 23, No.2 (Pure and Eng. Sciences), Pp 15-30, 2020 (Special Issue) $3^{\text {rd }}$ international conference on recent innovations in engineering (ICRIE) Duhok, September 9-10-2020

\begin{tabular}{|c|c|c|c|c|c|c|}
\hline 19 & China and Canada & 0 & 0.5 & $3,7,28$ & $30.91-41.05$ & $2.61-2.68$ \\
\hline 20 & Taiwan & $0-80$ & 0.24-0.72 & $1,3,7,28$ & $1-47.5$ & - \\
\hline 21 & China & $0-60$ & 0.5 & 28 & $35.6-47.5$ & - \\
\hline 22 & China and US & $0-40$ & 0.31 & 28 & 20.1-34.5 & - \\
\hline 23 & Thailand, Japan & $0-30$ & 0.45 & $3,7,28$ & $31-59$ & - \\
\hline 24 & India & $0-85$ & $0.22-0.79$ & 28 & $14.64-87$ & - \\
\hline 25 & Turkey & $0-70$ & $0.28-0.39$ & $1,3,7,28$ & $0-70.3$ & $1.3-4.59$ \\
\hline 26 & $\begin{array}{c}\text { Australia, USA, } \\
\text { Germany }\end{array}$ & $0-20$ & 0.45 & $3,7,14,28$ & $23.51-54.19$ & - \\
\hline 27 & Japan & $0-50$ & $0.37-0.56$ & 28 & $15-41$ & - \\
\hline 28 & India & $0-20$ & 0.38 & 28 & $35-39$ & - \\
\hline 29 & India & $0-50$ & 0.42 & 7,28 & $24.8-51.27$ & - \\
\hline 30 & Thailand & $0-50$ & $0.45-0.65$ & 28 & $16.6-50.4$ & - \\
\hline 31 & India & $0-30$ & 0.4 & 28 & $18-33$ & - \\
\hline 32 & Australia & $0-100$ & $0.3-0.4$ & 28 & $0-66$ & - \\
\hline 33 & India & 0 & $0.25-0.45$ & 28 & $34-88.6$ & - \\
\hline $\begin{array}{c}\text { Remark } \\
\text { s }\end{array}$ & 16 countries & $\begin{array}{c}\text { Ranged } \\
\text { from } 0 \% \text { to } \\
100 \%\end{array}$ & $\begin{array}{c}\text { Ranged } \\
\text { from } \\
0.22 \text { to } 1.2\end{array}$ & $\begin{array}{c}\text { Ranged from } \\
1 \text { day to } 28 \text { days }\end{array}$ & $\begin{array}{c}\text { Ranged from } \\
0 \mathrm{MPa} \text { to } \\
88.6 \mathrm{MPa}\end{array}$ & $\begin{array}{l}\text { Ranged from } \\
0.49 \mathrm{MPa} \text { to } \\
5 \mathrm{MPa}\end{array}$ \\
\hline
\end{tabular}

\subsection{Data modeling}

\subsubsection{Model of Vipulanandan correlation}

The Vipulanandan correlation model was used to predict the values of concrete modified with fly ash's mechanical properties. The following relationship was proposed based on the collected data:

$$
Y=Y_{O}+\frac{X}{A+(B .)}
$$

Tensile strength is $\mathrm{Y}$, dependent variable. Model parameters are Yo, A and B. Compressive strength is $\mathrm{X}$, the independent variables.

\subsubsection{Model predictions comparison}

Statistical quantification such as coefficient of determination $\left(\mathrm{R}^{\wedge} 2\right)$ and the root mean square error (RMSE) were found as follows:

$R^{2}=\left(\frac{\sum_{i}\left(x_{i}-\bar{x}\right)\left(y_{i}-\bar{y}\right)}{\sqrt{\sum_{i}\left(x_{i}-\bar{x}\right)^{2}} \times \sqrt{\sum_{i}\left(y_{i}-\bar{y}\right)^{2}}}\right)^{2}$

$$
R M S E=\sqrt{\frac{\sum_{i=1}^{\infty}\left(y_{i}-x_{i}\right)^{2}}{N}}
$$

Experimental values are $\mathrm{Yi}, \mathrm{xi}, \overline{\mathrm{y}}, \overline{\mathrm{x}}, \mathrm{N}$. Table 2 shows the values of the experimental, model of predicted value, actual test values and calculated values' mean, data amount, respectively.

\begin{tabular}{|c|c|c|c|c|c|}
\hline & $\begin{array}{l}\text { Statistical } \\
\text { Parameters }\end{array}$ & W/C & FA\% & $\begin{array}{c}\text { Comp strength }(\sigma \mathrm{c}) \\
(\mathrm{MPa}) \\
\text { (until 28 days) } \\
\end{array}$ & $\begin{array}{c}\text { Tensile strength }(\sigma \mathrm{t}) \\
\text { (MPa) } \\
\text { (until 28 days) } \\
\end{array}$ \\
\hline \multirow[t]{5}{*}{ Cement Concrete } & No. of data & 277 & - & 268 & 62 \\
\hline & Range & $0.22-1.2$ & - & $0-88.6$ & $1.21-5$ \\
\hline & Mean $(\mu)$ & 0.49 & - & 37.27 & 2.96 \\
\hline & Std. deviation $(\sigma)$ & 0.15 & - & 15.63 & 0.93 \\
\hline & $\operatorname{cov}(\%)$ & 30.59 & - & 41.94 & 31.51 \\
\hline \multirow{5}{*}{$\begin{array}{l}\text { Cement Concrete } \\
\text { modified with fly } \\
\text { ash }\end{array}$} & No. of data & 531 & 531 & 528 & 113 \\
\hline & Range & $0.24-0.66$ & $10-100$ & $0-86.41$ & $0.49-4.75$ \\
\hline & Mean $(\mu)$ & 0.42 & 36.19 & 30.34 & 2.37 \\
\hline & Std. deviation $(\sigma)$ & 0.074 & 20.23 & 13.25 & 1.115 \\
\hline & $\operatorname{cov}(\%)$ & 17.56 & 55.9 & 43.68 & 46.99 \\
\hline
\end{tabular}

Table (2): Properties of plain concrete and concrete with FA statistical analysis

rr14322@auis.edu.krd, ahmed.salih@auis.edu.krd

${ }^{1}$ Corresponding author: Engineering Department, American University of Iraq, Sulaimani, Sulaimani - Kirkuk 


\subsection{Nonlinear model for compressive strength (NLM)}

The evaluations were for the influence of water to cement ratio $(w / c)$, time of curing $(t)$, FA percentage, and $\mathrm{pH}$ on concrete's compression and tensile strength:

(i) Concrete (with $0 \%$ of $\mathrm{FA}$ ) and $\mathrm{pH}=7$ maximum compressive stress

$$
\sigma c=a(w / c)^{b}(t)^{c}
$$

(ii) Concrete (with $0 \%$ of $\mathrm{FA}$ ) and $\mathrm{pH} \neq 7$ maximum compressive stress

$$
\sigma c=a(w / c)^{b}(t)^{c}+d(w / c)^{e}(t)^{f}(p H)^{g}
$$

(iii) Concrete (with $0 \%<\mathrm{FA} \leq 25 \%$ ) and $\mathrm{pH}=7$ maximum compressive stress

$$
\sigma c=a(w / c)^{b}(t)^{c}+d(w / c)^{e}(t)^{f}(F A)^{g}
$$

(iv) Concrete (with $25 \%<\mathrm{FA} \leq 50 \%$ ) and $\mathrm{pH}=7$ maximum compressive stress

$$
\sigma c=a(w / c)^{b}(t)^{c}+d(w / c)^{e}(t)^{f}(F A)^{g}
$$

(v) Concrete (with $50 \%<\mathrm{FA} \leq 100 \%$ ) and $\mathrm{pH}=7$ maximum compressive stress $\sigma c=a(w / c)^{b}(t)^{c}+d(w / c)^{e}(t)^{f}(F A)^{g}$

(vi) Concrete (with $0 \%<\mathrm{FA} \leq 25 \%$ ) and $\mathrm{pH} \neq 7$ maximum compressive stress

$$
\sigma c=a(w / c)^{b}(t)^{c}+d(w / c)^{e}(t)^{f}(F A)^{g}+h(w / c)^{i}(t)^{j}(F A)^{k}(p H)^{l}
$$

(vii) Concrete (with $25 \%<\mathrm{FA} \leq 50 \%$ ) and $\mathrm{pH} \neq 7$ maximum compressive stress

$$
\sigma c=a(w / c)^{b}(t)^{c}+d(w / c)^{e}(t)^{f}(F A)^{g}+h(w / c)^{i}(t)^{j}(F A)^{k}(p H)^{l}
$$

(viii) Concrete (with $50 \%<\mathrm{FA} \leq 100 \%$ ) and $\mathrm{pH} \neq 7$ maximum compressive stress

$$
\sigma c=a(w / c)^{b}(t)^{c}+d(w / c)^{e}(t)^{f}(F A)^{g}+h(w / c)^{i}(t)^{j}(F A)^{k}(p H)^{l}
$$

The model parameters are a, b, c, d, e, f, g, h, i, j, k and 1 that were gotten from numerous lapse analysis with the method of least square from the collected data as shown in Tables 3.

rr14322@auis.edu.krd, ahmed.salih@auis.edu.krd

${ }^{1}$ Corresponding author: Engineering Department, American University of Iraq, Sulaimani, Sulaimani - Kirkuk 
Table (3): Nonlinear Model parameters for compression strength

Dep Variables (Y-axis) In-dep Variable

$$
\text { (X-axis) }
$$

\begin{tabular}{|c|c|c|c|c|c|c|c|c|c|c|c|c|c|c|c|c|c|c|}
\hline \multirow[t]{2}{*}{ Concrete } & $\begin{array}{c}\text { Comp strength of } \\
\text { concrete (with } 0 \% \text { of FA) } \\
\text { and } \mathrm{pH}=7\end{array}$ & $\begin{array}{l}\mathrm{w} / \mathrm{c}, \text { curing time } \\
\text { and } \mathrm{pH} \text { value }\end{array}$ & 10.99 & -0.99 & 0.22 & & & & & & & & & & 6.38 & 0.81 & 181 & Fig 9. \\
\hline & $\begin{array}{c}\text { Comp strength of } \\
\text { concrete (with } 0 \% \text { of } \mathrm{FA} \text { ) } \\
\text { and } \mathrm{pH} \neq 7\end{array}$ & & 10.99 & -0.99 & 0.22 & -9.54 & -0.08 & 0.27 & -0.79 & & & & & & 7.51 & 0.81 & 64 & Fig 10. \\
\hline \multirow[t]{5}{*}{$\begin{array}{l}\text { Concrete } \\
\text { with FA }\end{array}$} & $\begin{array}{c}\text { Comp strength of } \\
\text { concrete (with } 0 \%<\mathrm{FA} \leq \\
25 \% \text { )and } \mathrm{pH}=7\end{array}$ & $\begin{array}{c}\mathrm{w} / \mathrm{c}, \text { curing time, } \\
\mathrm{FA} \% \text { and } \mathrm{pH} \\
\text { value }\end{array}$ & 10.99 & -0.99 & 0.22 & 0.20 & -0.60 & 0.18 & 0.20 & & & & & & 3.22 & 0.86 & 116 & Fig 11. \\
\hline & $\begin{array}{l}\text { Comp strength of } \\
\text { concrete (with } 25 \%<\text { FA } \\
\leq 50 \% \text { ) and } p H=7\end{array}$ & & 10.99 & -0.99 & 0.22 & -15.96 & -0.89 & 0.18 & -0.38 & & & & & & 5.33 & 0.80 & 91 & Fig 12. \\
\hline & $\begin{array}{l}\text { Comp strength of } \\
\text { concrete (with } 50 \%<\text { FA } \\
\leq 100 \%) \text { ) and } \mathrm{pH}=7\end{array}$ & & 10.99 & -0.99 & 0.22 & -1.01 & -1.35 & 0.11 & 0.41 & & & & & & 4.38 & 0.81 & 62 & Fig 13. \\
\hline & $\begin{array}{l}\text { Comp strength of } \\
\text { concrete (with } 25 \%<\text { FA } \\
\leq 50 \% \text { ) and } \mathrm{pH} \neq 7\end{array}$ & & 10.99 & -0.99 & 0.22 & -15.96 & -0.89 & 0.18 & -0.38 & -0.02 & -2.08 & 0.67 & 0.69 & -0.49 & 1.69 & 0.83 & 25 & Fig 15. \\
\hline & $\begin{array}{l}\text { Comp strength of } \\
\text { concrete (with } 50 \%<\mathrm{FA} \\
\leq 100 \% \text { ) and } \mathrm{pH} \neq 7\end{array}$ & & 10.99 & -0.99 & 0.22 & -1.01 & -1.35 & 0.11 & 0.41 & -14.4 & -26.18 & 1.85 & -8.26 & -2.95 & 2.83 & 0.86 & 14 & Fig 16. \\
\hline
\end{tabular}

rr14322@auis.edu.krd, ahmed.salih@auis.edu.krd

${ }^{1}$ Corresponding author: Engineering Department, American University of Iraq, Sulaimani, Sulaimani - Kirkuk Rd, Sulaimania 


\section{RESULTS, DISCUSSION AND ANALYSES}

\subsection{The analysis of the statistics}

\subsubsection{Water to cement ratio, $(w / c)$}

From the literature, 277 data of w/c were of plain concrete, which had the w/c ranged between 0.22 and 1.2 , a mean of 0.49 , coefficient of variation (COV) of $30.59 \%$ and the standard deviation of 0.15 as shown in Table
2. The w/c data ranging between 0.3 and 0.5 compiled $70 \%$ of total data. Based on the 531 water to cement ratio data shown in Table 2, the water to cement ratio had a mean of 0.42 , SD of 0.074 , COV of $17.56 \%$ and ranged from 0.24 to 0. 66. Also, as shown in Figure1, more than $70 \%$ of overall water to cement ratio of concrete with FA was between 0.3 and 0.5 .

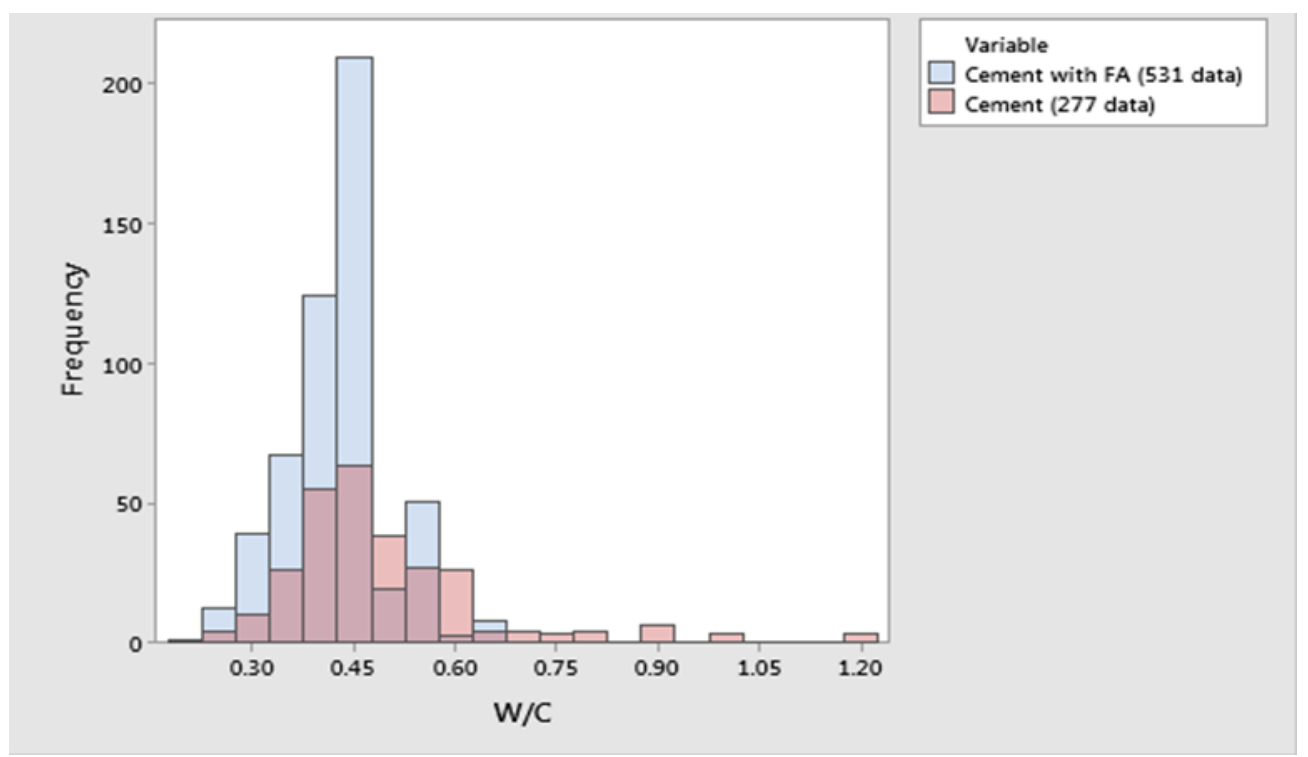

Fig. (1): Histogram of Frequency of W/C corresponding to cement and cement with FA

\subsubsection{Fly Ash ( FA\%)}

According to the overall 531 data of FA percentages that were used to modify concrete, FA percentages were changing from $10 \%$ to $100 \%$, the mean $36.19 \%$, COV of $55.9 \%$, and
SD of $20.23 \%$ demonstrated in Table $2.58 \%$ of the FA ranged from $15 \%-30 \%$. Moreover, only $30 \%$ of the total FA percentage data was above $50 \%$ FA content shown in Figure 2.

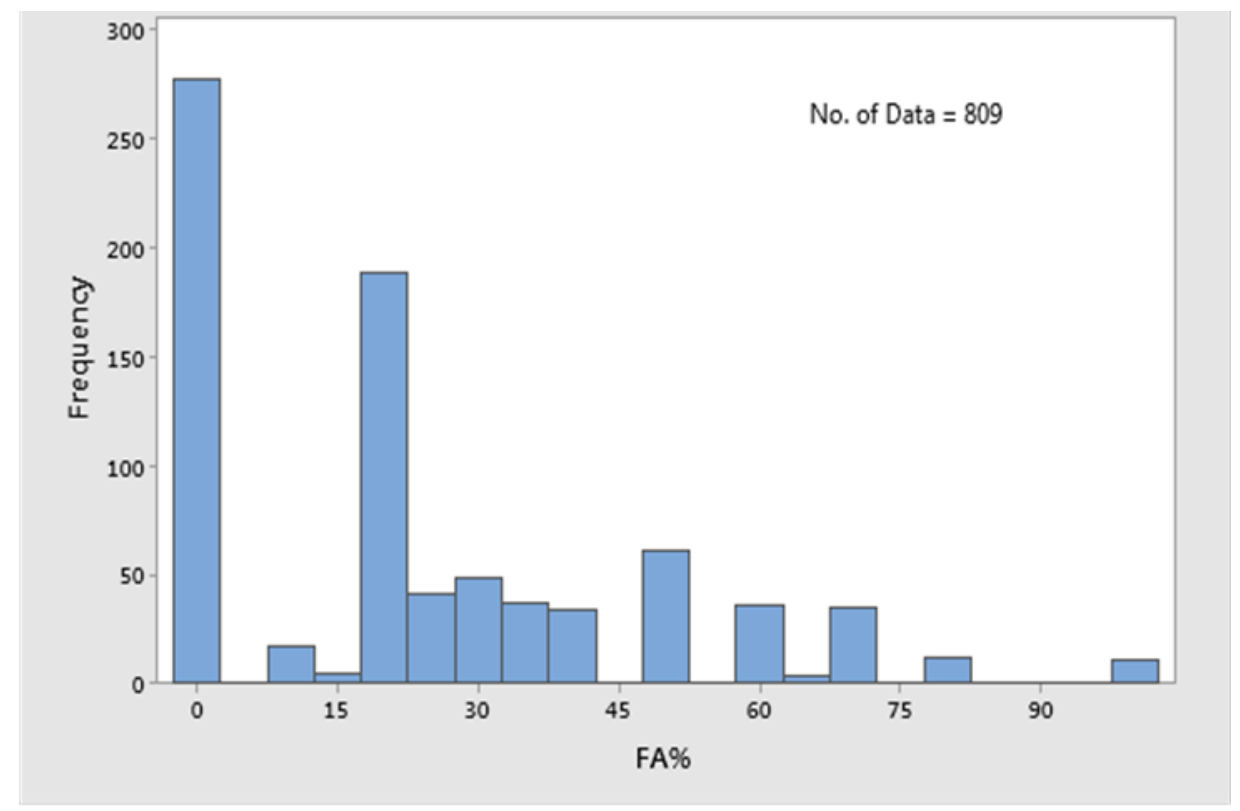

rr14322@auis.edu.krd, ahmed.salih@auis.edu.krd

${ }^{1}$ Corresponding author: Engineering Department, American University of Iraq, Sulaimani, Sulaimani - Kirkuk

$\mathrm{Rd}$, Sulaimania 


\subsection{Mechanical properties}

\subsubsection{Maximum compressive stress $(\sigma c)$}

\subsubsection{Concrete with 0\% $\mathrm{FA}$}

From 268 data concrete's compressive strengths gathered from the literature, shown in Table 1, $\sigma \mathrm{c}$ ranged between 0 and $88.6 \mathrm{MPa}$,
Fig. (2): Histogram of FA percentages

37.27 MPa mean value, SD of $15.63 \mathrm{MPa}$ and COV of $41.94 \%$, summarized in Table 2. The histogram shows $55 \%$ of the compressive strength ranged from 20-45 MPa. 25\% of the data was more than $50 \mathrm{MPa}$, and $20 \%$ of the data was fewer than $20 \mathrm{MPa}$, shown in Figure 3.

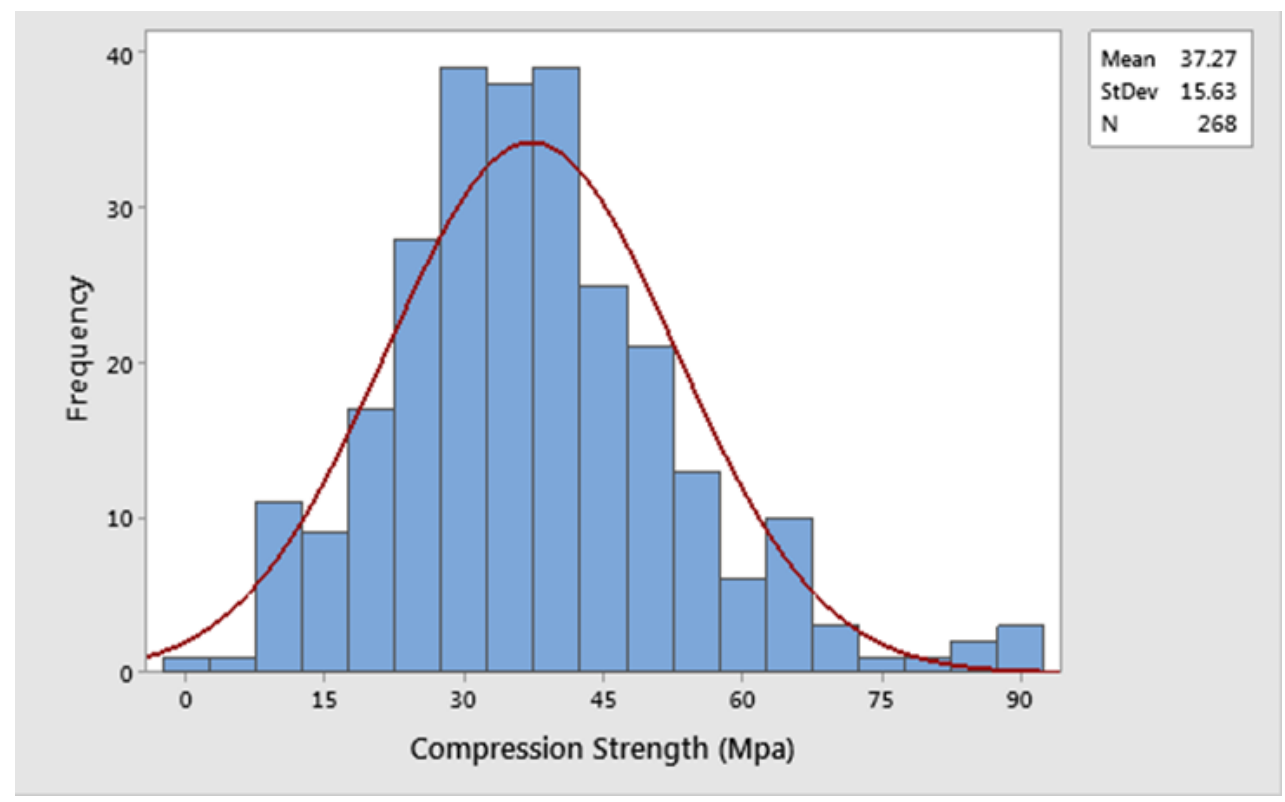

Fig. (3): Histogram of Compression Strength without FA

\subsubsection{Concrete with $F A$}

Referring to 528 data of concrete with FA's ultimate compressive stress collected, Table 2, $\sigma \mathrm{c}$ varied between 0 and $86.41 \mathrm{MPa} 30.34 \mathrm{MPa}$ mean value, SD of $13.25 \mathrm{MPa}$ and $43.68 \%$ $\mathrm{COV}$. The histogram of $\sigma \mathrm{c}$ for concrete with fly ash cured for up to 28 days, $56 \%$ of the data ranged between $20-45 \mathrm{MPa}$. $30 \%$ of the data had a value higher than $50 \mathrm{MPa}$, and $14 \%$ of the data had a value of less than $20 \mathrm{MPa}$, demonstrated in Figure 4.

rr14322@auis.edu.krd, ahmed.salih@auis.edu.krd

${ }^{1}$ Corresponding author: Engineering Department, American University of Iraq, Sulaimani, Sulaimani - Kirkuk Rd, Sulaimania 


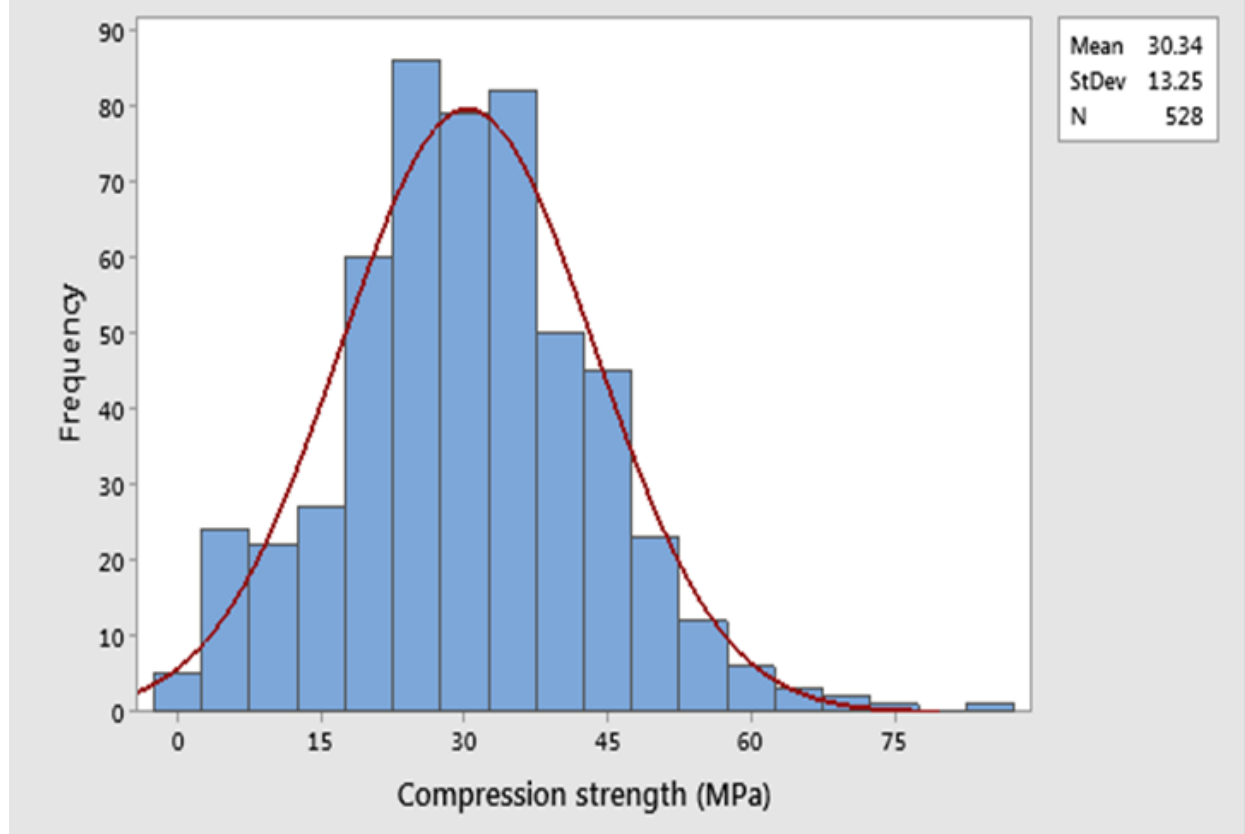

\subsubsection{Tensile strength $(\sigma t)$}

Fig. (4): Histogram of Compression Strength with FA

\subsubsection{Concrete (with 0\% FA)}

62 tensile strengths data of plain concrete were gathered in Table 1 . The tensile strength varied from 1.21 to $5 \mathrm{MPa}$ with $2.96 \mathrm{MPa}$ mean value, $\mathrm{COV}$ of $31.51 \%$, and $0.93 \mathrm{MPa} \mathrm{SD}$ value, as in Table 2.

\subsubsection{Concrete modified with $F A$}

113 tensile strengths data of concrete with FA were composed of the literature, Table 2. The tensile strength of concrete with fly ash varied between 0.49- 4.75 MPa, 2.37 MPa mean,SD of $1.115 \mathrm{MPa}$ and $46.99 \% \mathrm{COV}$, displayed in Table 2.

\subsection{Property correlations}

3.3.1Compressive strength' relationship with water to cement ratio, curing time, $\mathrm{pH}$ level and FA\% of concrete

793 data of concrete's optimum compression stress that was cured up to 28 days was gathered from literature and relationships' properties were examined between the compressive strength, FA content, $\mathrm{pH}$ value and water to cement ratio. Poor or non-existing relationships were detected between compressive strength and FA\%, $\mathrm{pH}$ and water to cement ration that was cured up to 28 days, presented in Fig.5, 6, 7, 8.

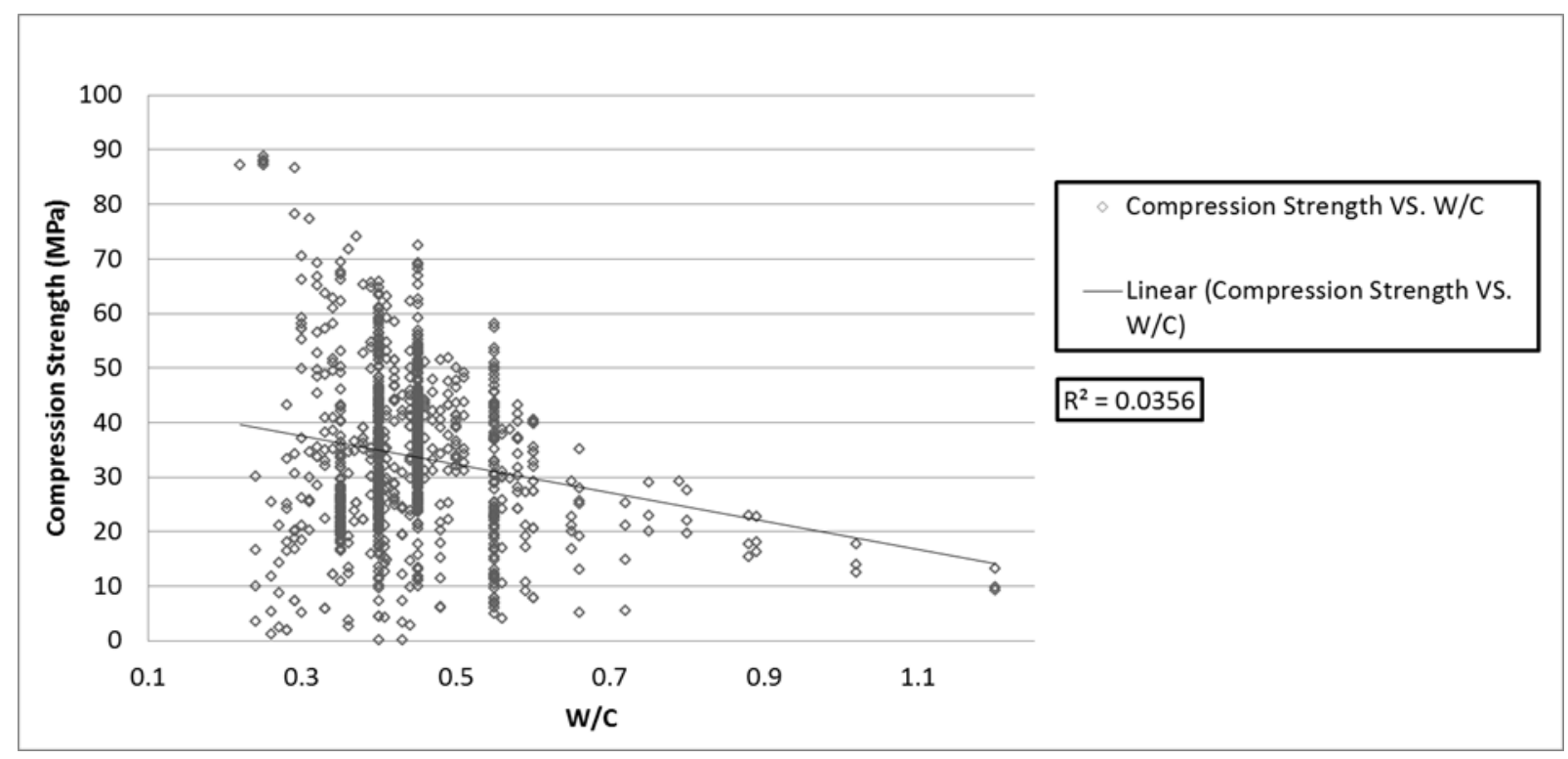

Fig. (5): Compression Strength vs. W/C

rr14322@auis.edu.krd, ahmed.salih@auis.edu.krd

${ }^{1}$ Corresponding author: Engineering Department, American University of Iraq, Sulaimani, Sulaimani - Kirkuk

$\mathrm{Rd}$, Sulaimania 


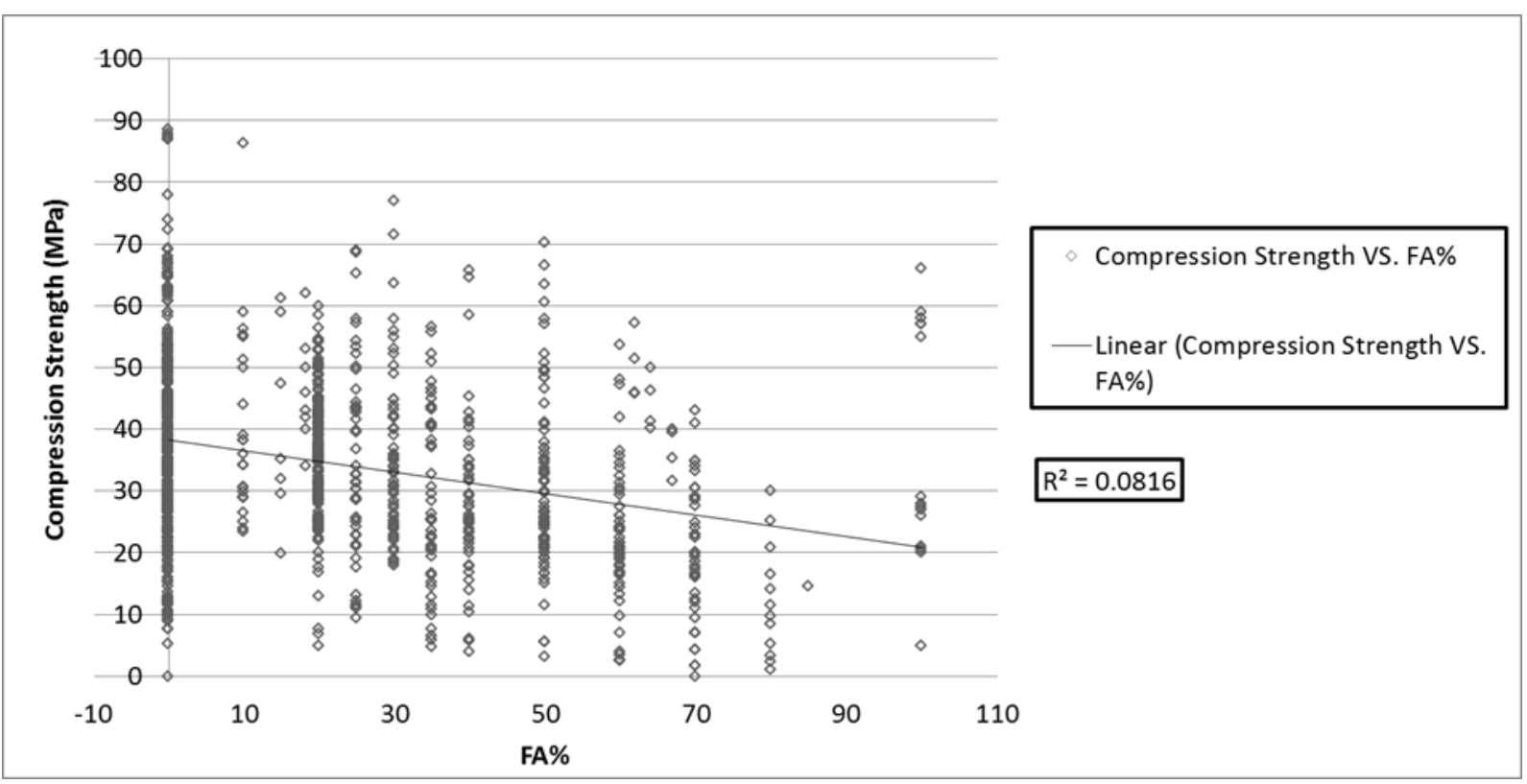

Fig. (6): Compression Strength vs. FA\%

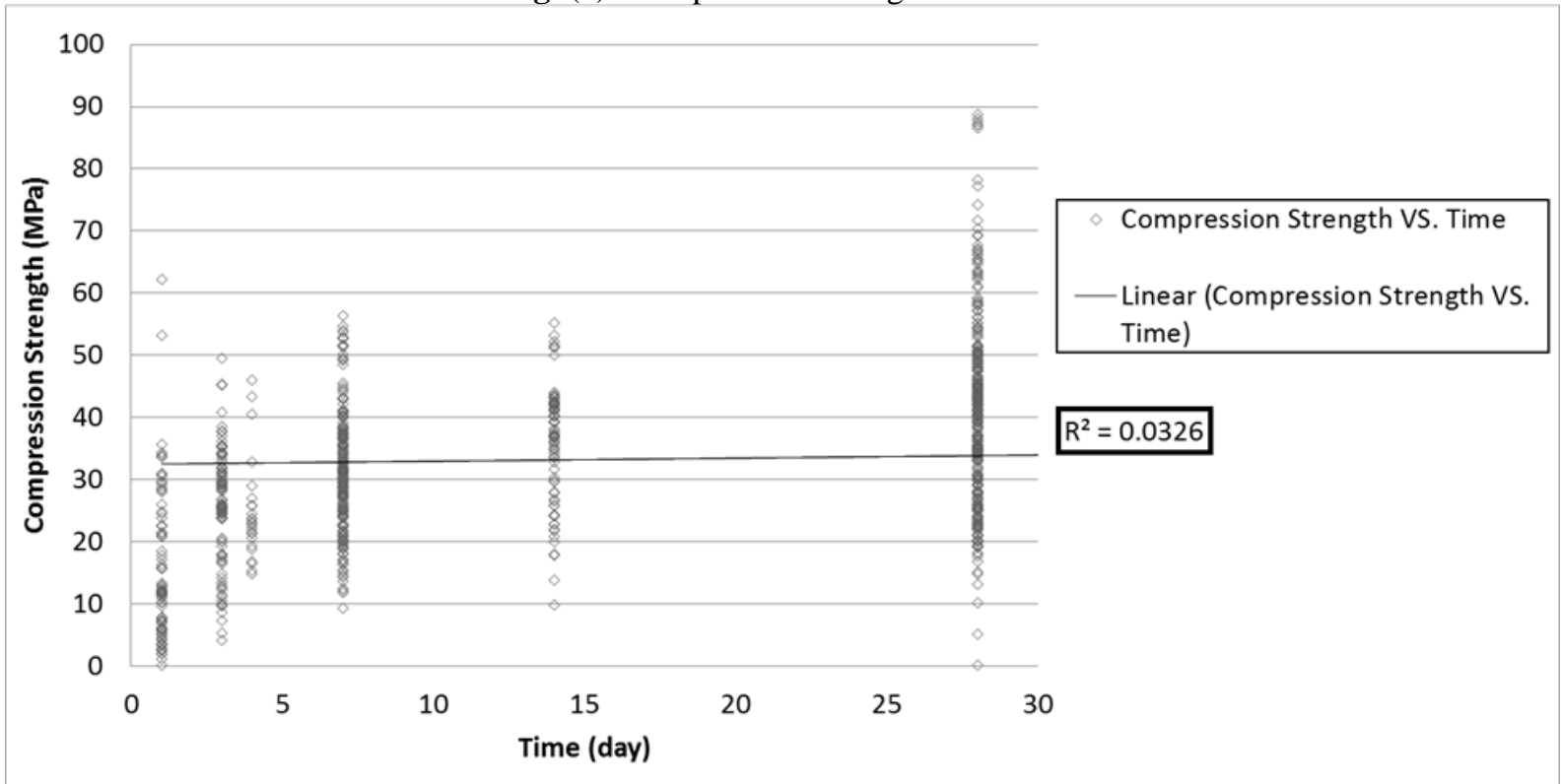

Fig. (7): Compression Strength vs. Curing time

rr14322@auis.edu.krd, ahmed.salih@auis.edu.krd

${ }^{1}$ Corresponding author: Engineering Department, American University of Iraq, Sulaimani, Sulaimani - Kirkuk $\mathrm{Rd}$, Sulaimania 


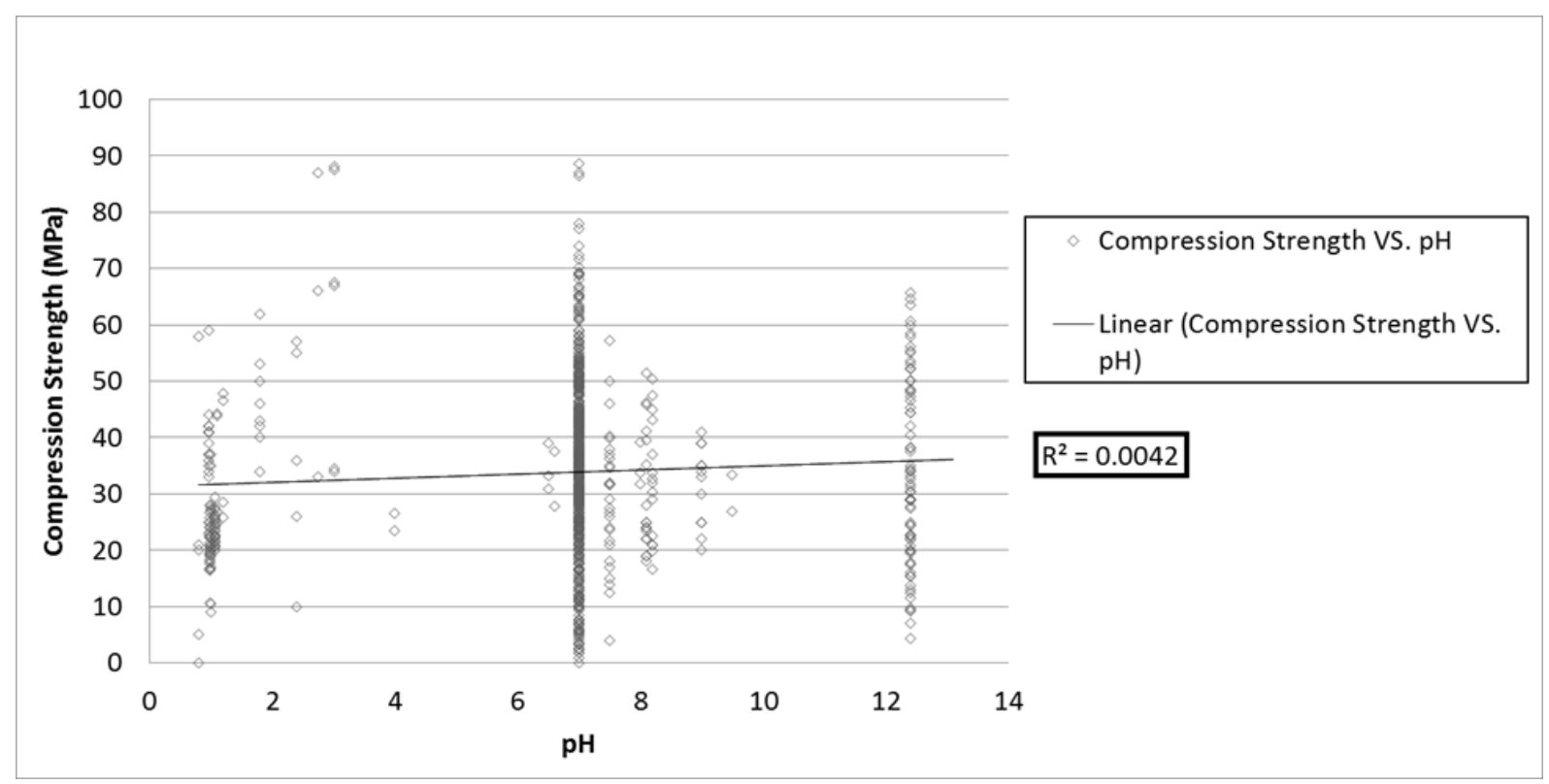

Fig. (8): Compression Strength vs. pH

3.3.2Measured compressive strength and predicted compressive strength relationship

Because no relative correlation between the compressive strength, curing time, $\mathrm{pH}, \mathrm{FA} \%$, and water to cement ratio was detected, the max compressive stress was related to $\mathrm{pH}$ value, FA\%, water to cement ration and curing period as independent variables via a nonlinear correlation. The parameters of the relationships were gained with the least square method that uses multiple regression analyses.

The main observation was that the w/c ratio has the highest effect on compression strength. Table 3 summarizes the $\mathrm{R}^{\wedge} 2$, parameters, RMSE and the amount of data. measured and calculated compressive strength had decent relations, shown in Figures 9, 10, 11, 12, 13, 14, 15, 16.

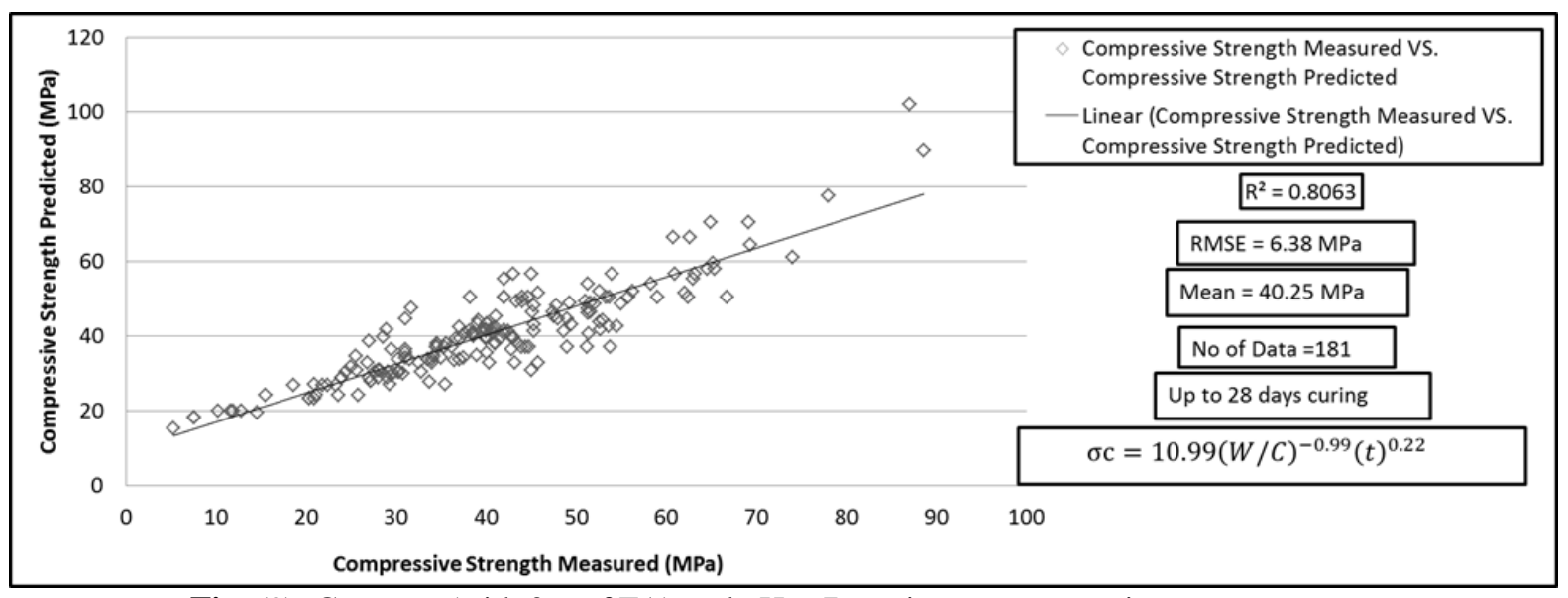

Fig. (9): Concrete (with $0 \%$ of $\mathrm{FA}$ ) and $\mathrm{pH}=7$ maximum compressive stress

rr14322@auis.edu.krd, ahmed.salih@auis.edu.krd

${ }^{1}$ Corresponding author: Engineering Department, American University of Iraq, Sulaimani, Sulaimani - Kirkuk 


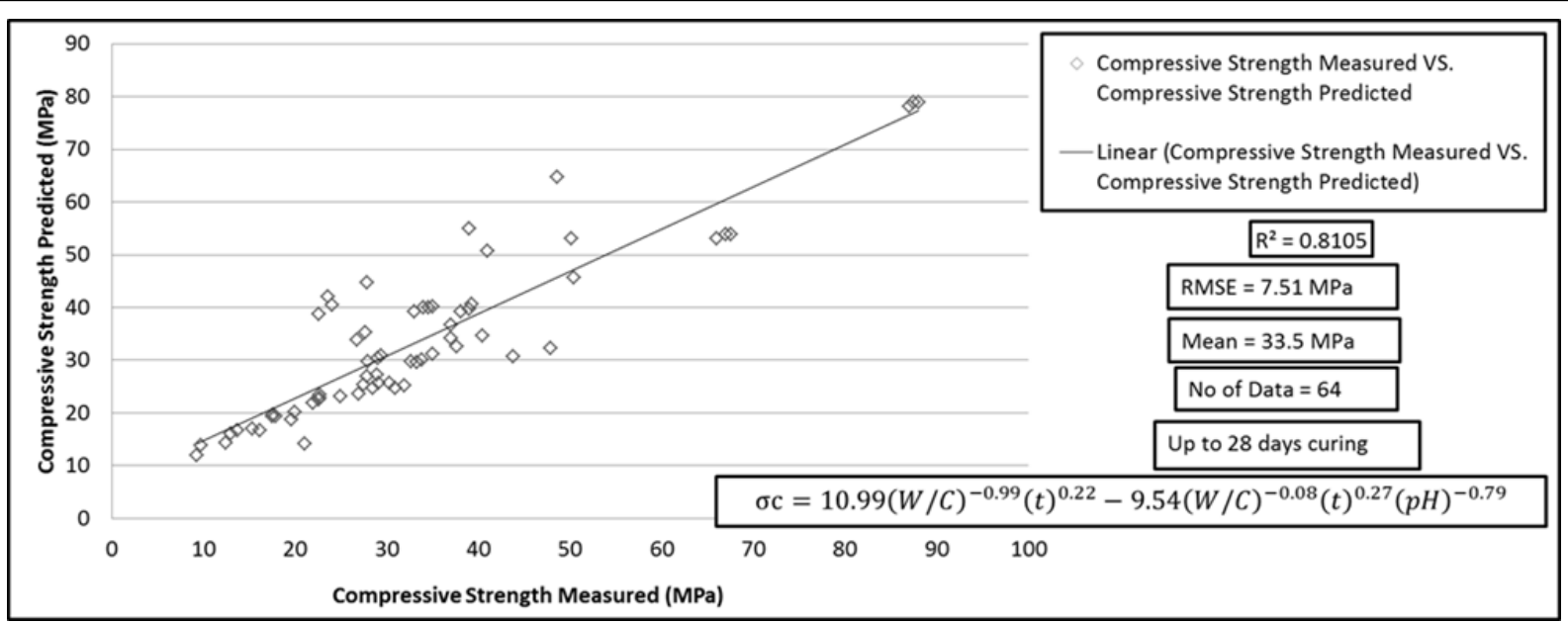

Fig. (10): Concrete (with $0 \%$ of $\mathrm{FA}$ ) and $\mathrm{pH} \neq 7$ maximum compressive stress

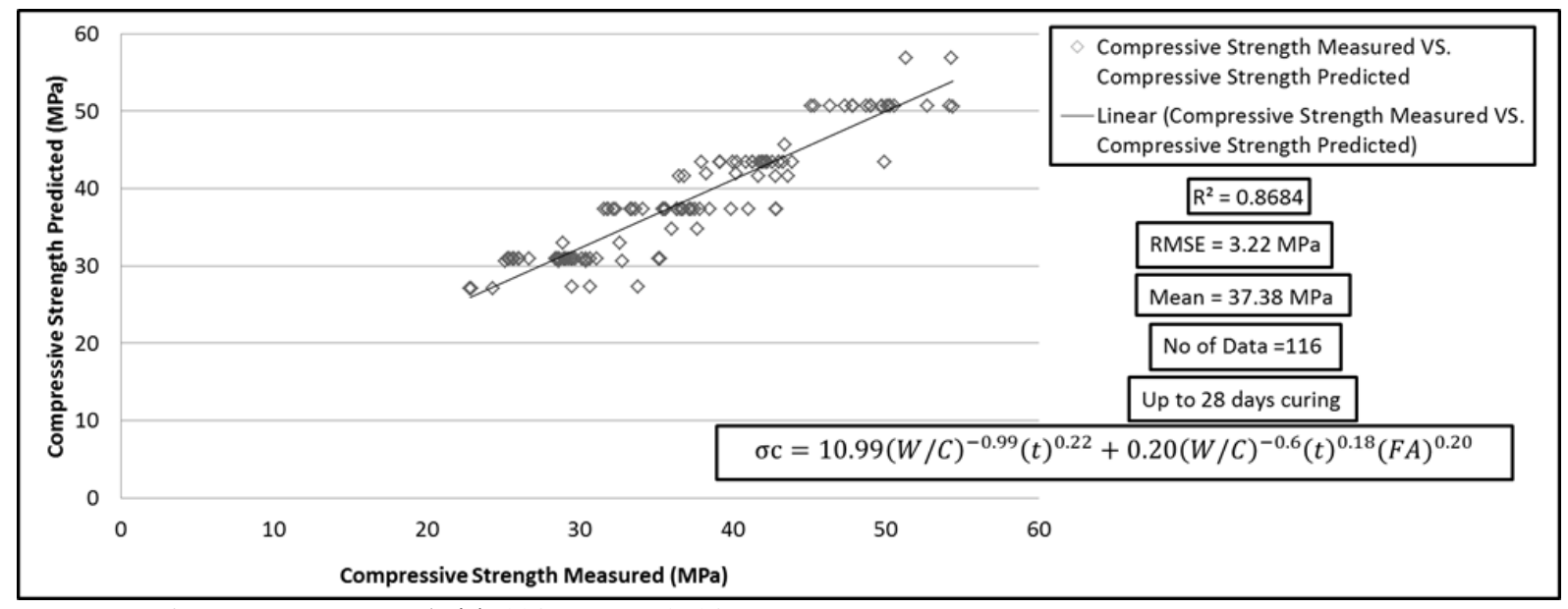

Fig. (11): Concrete (with $0 \%<\mathrm{FA} \leq 25 \%$ ) and $\mathrm{pH}=7$ maximum compressive stress

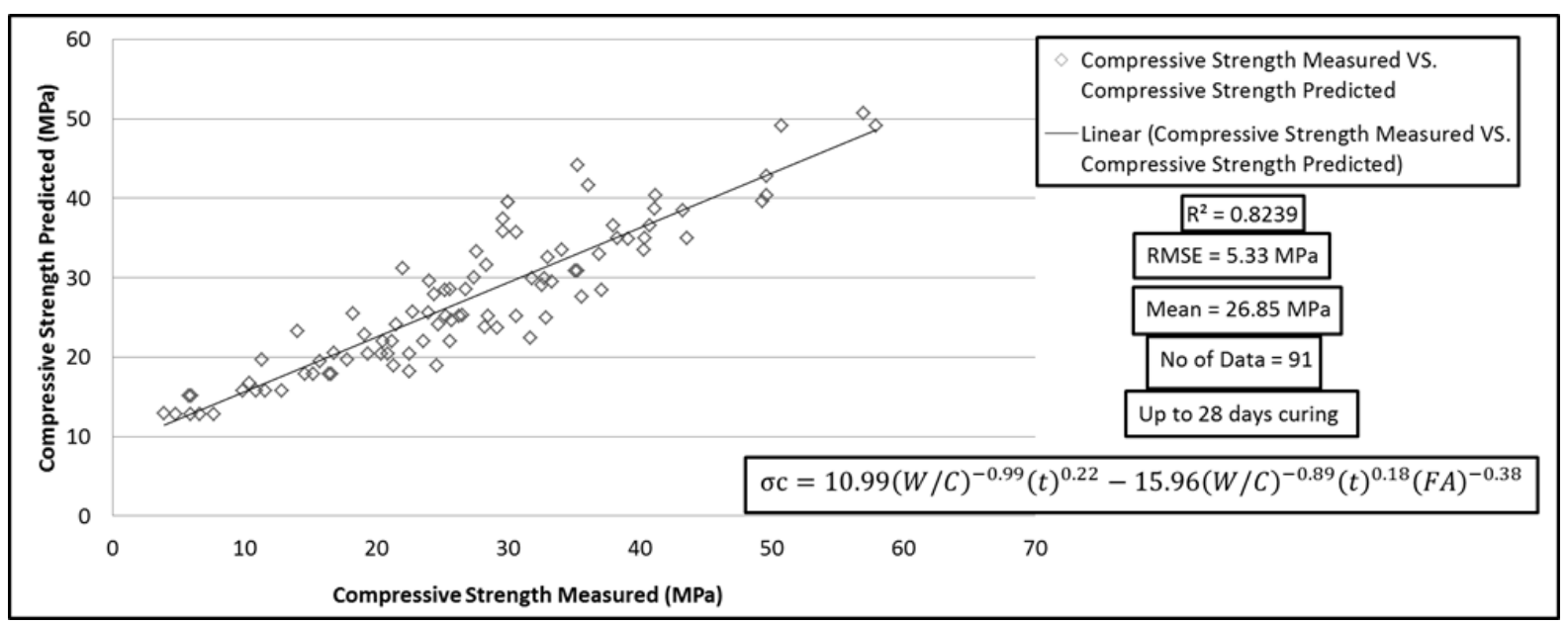

Fig. (12): Concrete (with $25 \%<\mathrm{FA} \leq 50 \%$ ) and $\mathrm{pH}=7$ maximum compressive stress

rr14322@auis.edu.krd, ahmed.salih@auis.edu.krd

${ }^{1}$ Corresponding author: Engineering Department, American University of Iraq, Sulaimani, Sulaimani - Kirkuk Rd, Sulaimania 


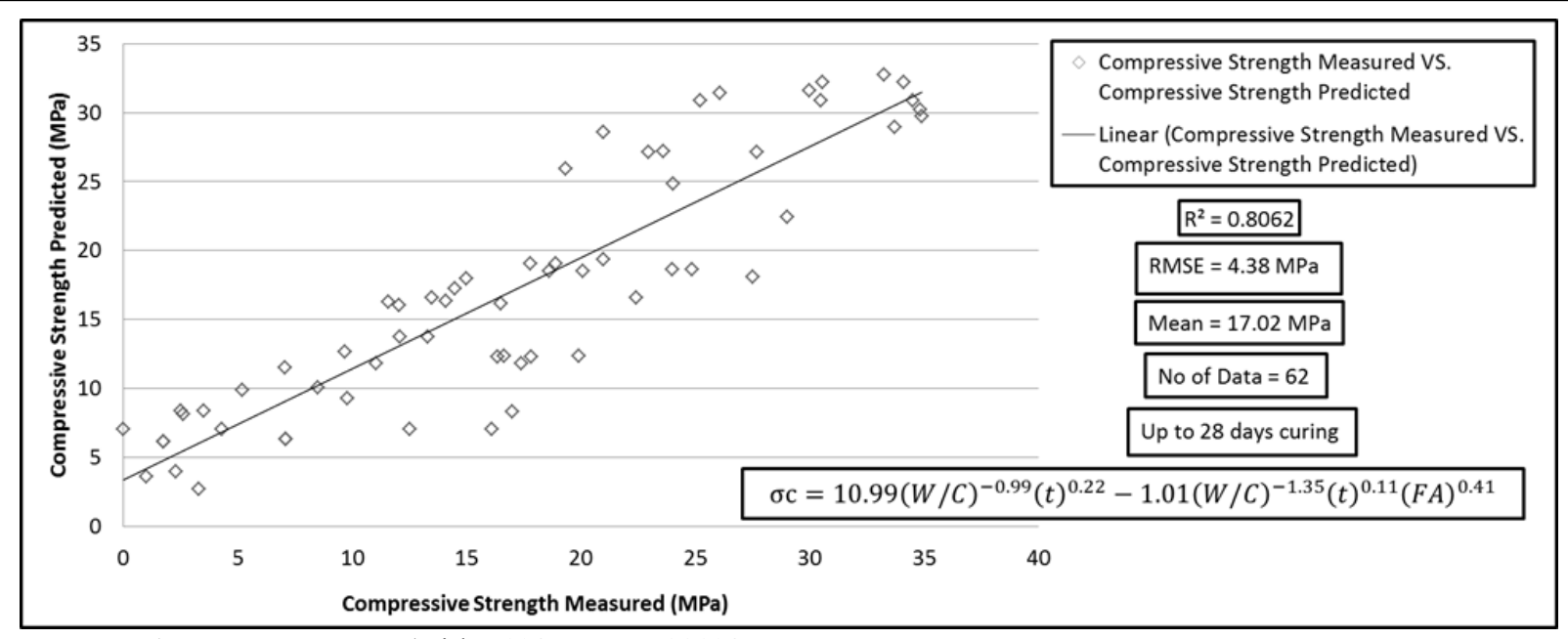

Fig. (13): Concrete (with $50 \%<\mathrm{FA} \leq 100 \%$ ) and $\mathrm{pH}=7$ maximum compressive stress

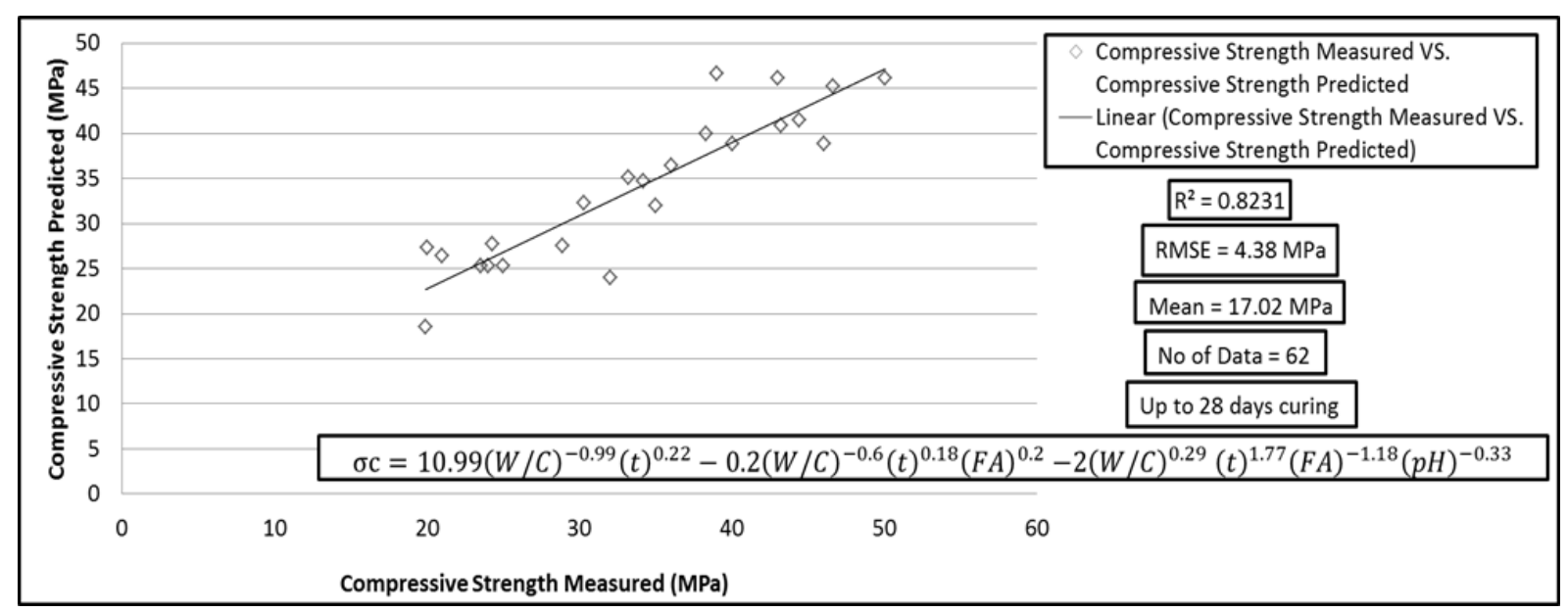

Fig. (14): Concrete (with $0 \%<\mathrm{FA} \leq 25 \%$ ) and $\mathrm{pH} \neq 7$ maximum compressive stress

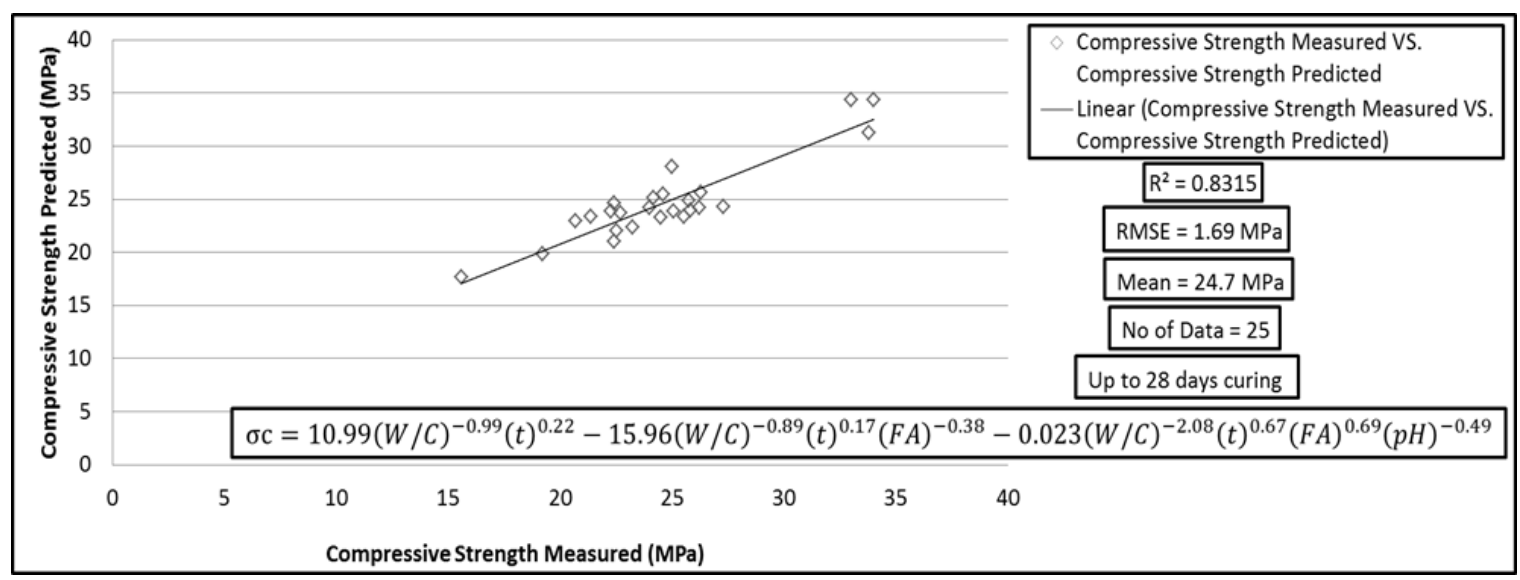

Fig. (15): Concrete (with $25 \%<\mathrm{FA} \leq 50 \%$ ) and $\mathrm{pH} \neq 7$ maximum compressive stress

rr14322@auis.edu.krd, ahmed.salih@auis.edu.krd

${ }^{1}$ Corresponding author: Engineering Department, American University of Iraq, Sulaimani, Sulaimani - Kirkuk

$\mathrm{Rd}$, Sulaimania 


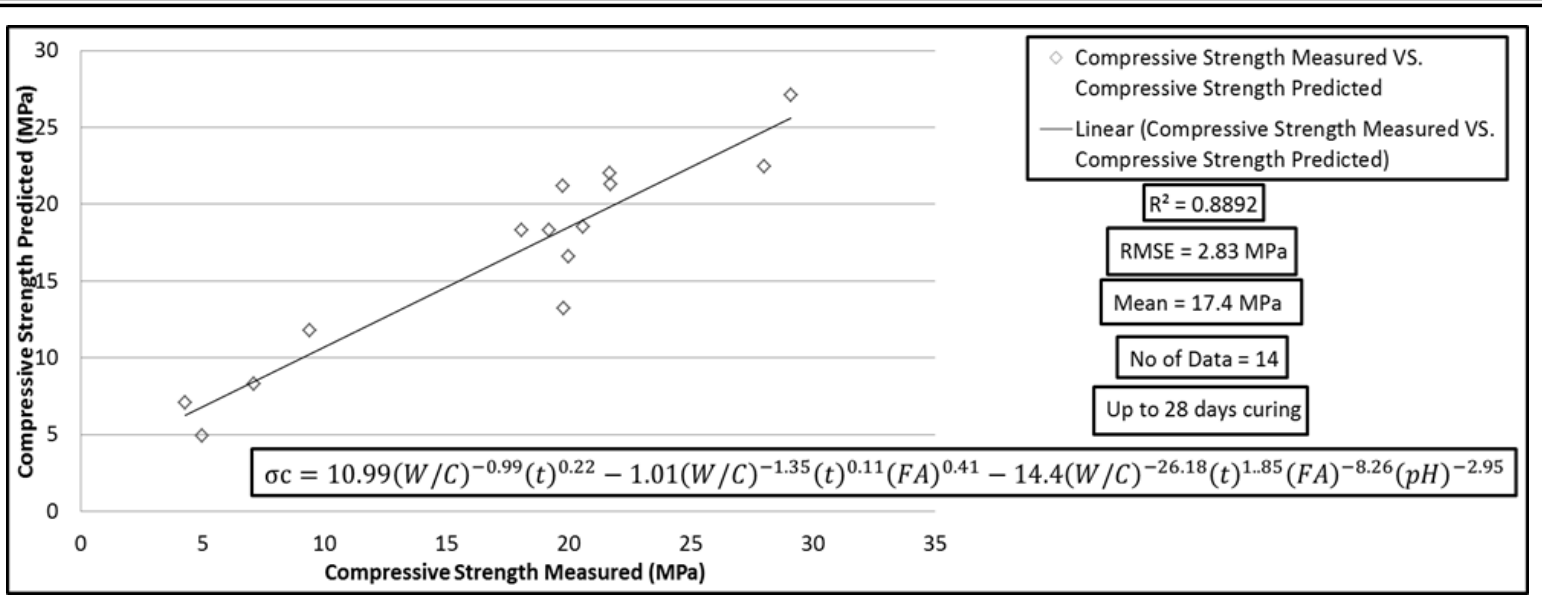

Fig. (16): Concrete (with 50\% $<\mathrm{FA} \leq 100 \%$ ) and $\mathrm{pH} \neq 7$ maximum compressive stress

\subsubsection{Compressive strength and tensile strength correlation}

The model of the Vipulanandan correlation was utilized for relating between tensile and compression strength, Figure 17. The model showed a great relation between tensile measured and predicted as long as with compression vs tensile graph, making $\mathrm{R}^{\wedge} 2$ be 0.99, Fig.18. Using the value of compressive strength, the tensile can be calculated with the equation below.

$$
\sigma t=0.083+\frac{\sigma c}{10.59+(0.095 * \sigma c)}
$$

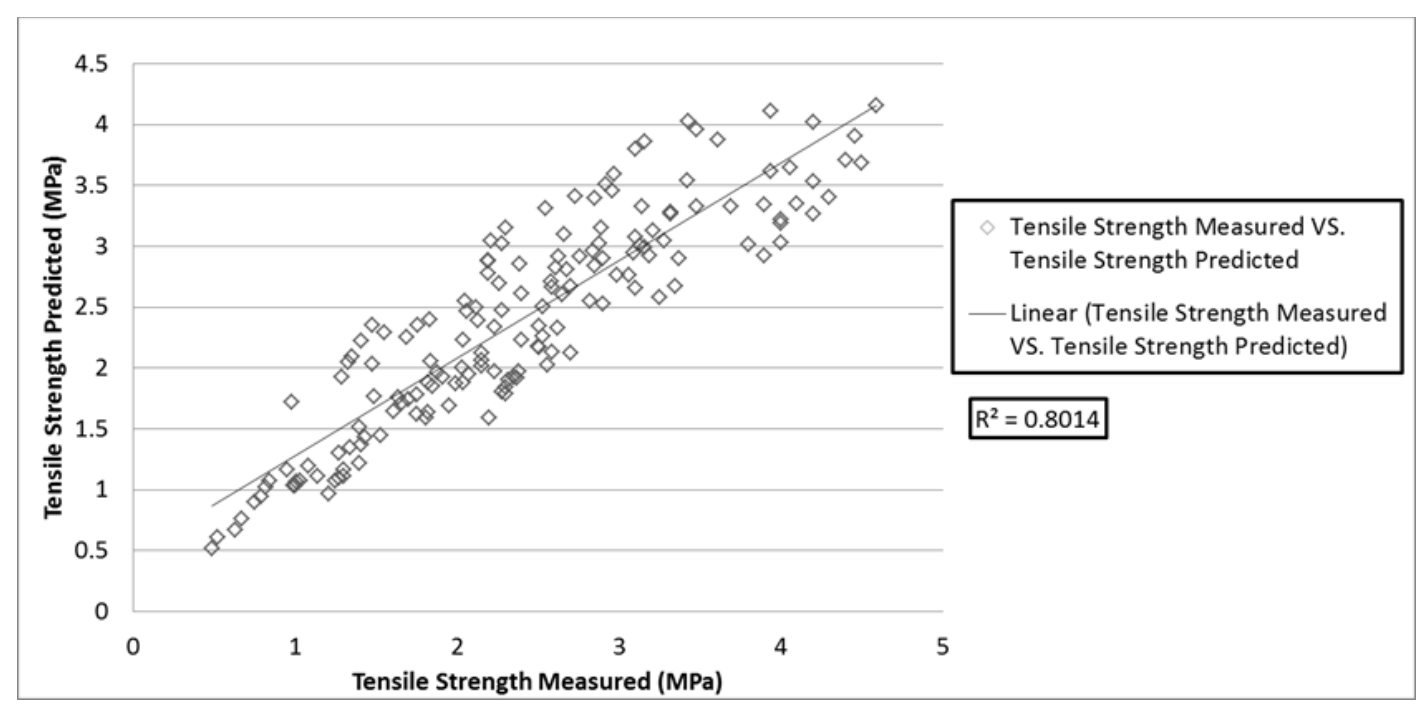

Fig. (17): Tensile strength measured vs. predicted

rr14322@auis.edu.krd, ahmed.salih@auis.edu.krd

${ }^{1}$ Corresponding author: Engineering Department, American University of Iraq, Sulaimani, Sulaimani - Kirkuk Rd, Sulaimania 


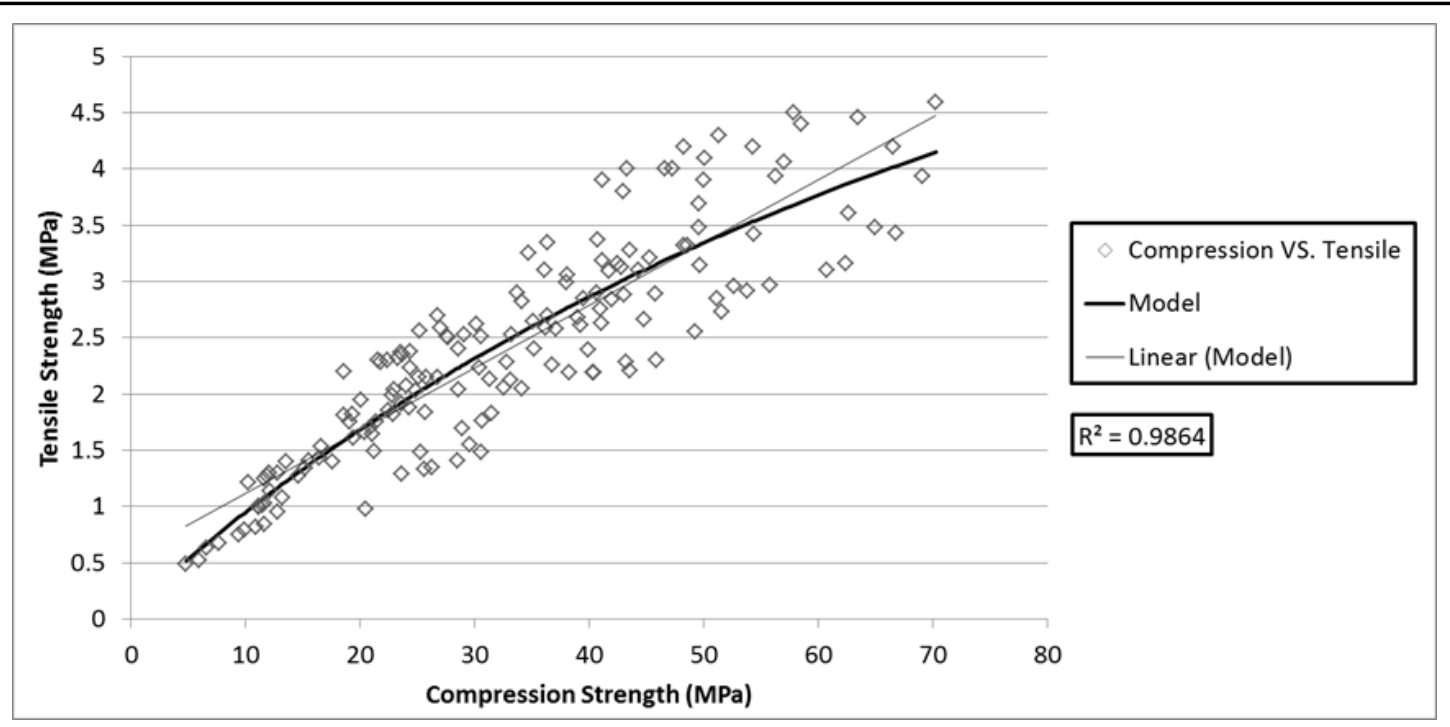

Fig. (18): Compression strength vs. Tensile strength and tensile model

\section{CONCLUSION}

This study's purpose was to know how different $\mathrm{pHs}$ of curing liquid will affect concrete, also to see if adding FA will make the concrete more durable and resistive to these $\mathrm{pH}$ harsh environments. The water to cement or binder ratio and curing time are major parameters in any concrete application to understand the full picture of what this concrete is supposed to do and what are the expectations. From many references, literature was collected to develop relationships, models, and formulas. The main conclusions were; correlations were not found between compressive strength water to cement ratio, curing time, $\mathrm{pH}$ and Fly ash percentage, more does not mean more when it comes to FA\% in concrete because it will lead the concrete to lose its bonding properties, lower FA\% had better performance; the higher fly ash percentage weakened the concrete. The best W/C ratio is $0.35-0.45$. The Nonlinear model parameters show that water to cement ratio has the most effect on concrete's strength, then curing time than any FA\% in small quantities. Overall, according to the parameters and the data observation, FA has a role in making concrete have better resistance to high and low pHs.

\section{REFERENCES}

Al-Jabri, K., Al-Saidy, A., Taha, R., \& Al-Kemyani, A. (2011). Effect of using Wastewater on the Properties of High Strength Concrete. Procedia Engineering, 14, 370-376. doi:10.1016/j.proeng.2011.07.046

Ariffin, M., Bhutta, M., Hussin, M., Tahir, M. M., \& Aziah, N. (2013). Sulfuric acid resistance of blended ash geopolymer concrete. Construction and Building Materials,43, 8086. doi:10.1016/j.conbuildmat.2013.01.018

Atiş, C. D. (2003). High-Volume Fly Ash Concrete with High Strength and Low Drying Shrinkage. Journal of Materials in Civil Engineering, 15(2),

153-156. doi:10.1061/(asce)0899-1561(2003)15:2(153)

Atiş, C. D. (2005). Strength properties of highvolume fly ash roller compacted and workable concrete, and influence of curing condition. Cement and Concrete Research,35(6), 11121121. doi:10.1016/j.cemconres.2004.07.037

Aydın, S., Yazıcı, H., Yiğiter, H., \& Baradan, B. (2007). Sulfuric acid resistance of highvolume fly ash concrete. Building and Environment,42(2), 717-721. doi:10.1016/j.buildenv.2005.10.024

Bakharev, T. (2005). Resistance of geopolymer materials to acid attack. Cement and Concrete Research,35(4), doi:10.1016/j.cemconres.2004.06.005

Barbhuiya. (2017). Behaviour of a Sustainable Concrete in Acidic Environment. Sustainability,9(9), 1556. doi:10.3390/su9091556

Burhan, L., Ghafor, K., \& Mohammed, A. (2020). Enhancing the Fresh and Hardened Properties of the Early Age Concrete Modified with Powder Polymers and Characterized Using Different Models. Advances in Civil Engineering Materials, 9(1), 227-249.

Burhan, L., Ghafor, K., \& Mohammed, A. (2019). Modeling the effect of silica fume on the compressive, tensile strengths and durability of NSC and HSC in various strength ranges. Journal of Building Pathology and Rehabilitation,4(1). doi:10.1007/s41024-0190058-4 Chalee, W., Ausapanit, P., \& Jaturapitakkul, C. rr14322@auis.edu.krd, ahmed.salih@auis.edu.krd

${ }^{1}$ Corresponding author: Engineering Department, American University of Iraq, Sulaimani, Sulaimani - Kirkuk Rd, Sulaimania 
(2010). Utilization of fly ash concrete in marine environment for long term design life analysis. Materials \& Design,31(3), 12421249. doi:10.1016/j.matdes.2009.09.024

Chen, H., Li, L. G., Lai, Z., Kwan, A. K., Chen, P., \& Ng, P. L. (2019). Effects of Crushed Oyster Shell on Strength and Durability of Marine Concrete Containing Fly Ash and Blastfurnace Slag. Materials Science,25(1). doi:10.5755/j01.ms.25.1.18772

De Belie. (1998). 98/02137 Use of fly ash or silica fume to increase the resistance of concrete to feed acids. Fuel and Energy Abstracts,39(3), 193. doi:10.1016/s0140-6701(98)80331-7

Dinakar, P., Babu, K., \& Santhanam, M. (2008). Durability properties of high volume fly ash self compacting concretes. Cement and Concrete Composites,30(10), 880-886. doi:10.1016/j.cemconcomp.2008.06.011

Dugarte, M., Martinez-Arguelles, G., \& Torres, J. (2018). Experimental Evaluation of Modified Sulfur Concrete for Achieving Sustainability in Industry Applications. Sustainability,11(1), 70. doi:10.3390/su11010070

Goyal, S., Kumar, M., Sidhu, D. S., \& Bhattacharjee, B. (2009). Resistance of Mineral Admixture Concrete to Acid Attack. Journal of Advanced Concrete Technology,7(2), 273-283. doi:10.3151/jact.7.273

Haufe, J., \& Vollpracht, A. (2019). Tensile strength of concrete exposed to sulfate attack. Cement and Concrete Research,116, 81-88. doi:10.1016/j.cemconres.2018.11.005

High-Performance Concrete Incorporating Rice Husk Ash as a Supplementary Cementing Material. (1996). ACI Materials Journal,93(6). doi:10.14359/9870

Huang, C., Lin, S., Chang, C., \& Chen, H. (2013). Mix proportions and mechanical properties of concrete containing very high-volume of Class F fly ash. Construction and Building Materials,46, 71-78. doi:10.1016/j.conbuildmat.2013.04.016

Kaniraj, S. R., \& Gayathri, V. (2003). Factors Influencing the Strength of Cement Fly Ash Base Courses. Journal of Transportation Engineering, 129(5), doi:10.1061/(asce)0733947x(2003)129:5(538)

Kim. (2018). Fly ash particle characterization for predicting concrete compressive strength. Construction and Building Materials.

Kou, S. C., Poon, C. S., \& Chan, D. (2007). Influence of Fly Ash as Cement Replacement on the Properties of Recycled Aggregate Concrete. Journal of Materials in Civil Engineering,19(9), 709-717. doi:10.1061/(asce)0899-1561(2007)19:9(709)

Kumar, S. (2000). Influence of water quality on the strength of plain and blended cement concretes in marine environments. Cement and Concrete Research,30(3), 345-350. doi:10.1016/s00088846(99)00263-x

Li. (2018). Resistance of recycled aggregate concrete containing low- and high-volume fly ash against the combined action of freeze-thaw cycles and sulfate attack. Construction and Building Materials.

Mazur, P., Mikuła, J., \& Kowalski, J. (2013). The Corrosion Resistance Of The Base Geopolymer Fly Ash. Advances in Science and Technology - Research Journal,7(19), 8892. doi: $10.5604 / 20804075.1062704$

Meddah, M. S., Zitouni, S., \& Belâabes, S. (2010). Effect of content and particle size distribution of coarse aggregate on the compressive strength of concrete. Construction and Building Materials,24(4), 505-512. doi:10.1016/j.conbuildmat.2009.10.009

Mehta, P. (1985). Studies on chemical resistance of low water/cement ratio concretes. Cement and Concrete Research,15(6), 969-978. doi:10.1016/0008-8846(85)90087-0

Mohammed, Ahmed, and Wael Mahmood. "Estimating the efficiency of the sandy soilscement based grout interactions from particle size distribution (PSD)." Geomechanics and Geoengineering (2019): 1-18, https://doi.org/10.1080/17486025.2019.16453 61.

Mahmood, Wael, and Ahmed Mohammed. "Hydraulic Conductivity, Grain Size Distribution (GSD) and Cement Injectability Limits Predicted of Sandy Soils Using Vipulanandan Models." Geotechnical and Geological Engineering (2019): 1-20, https://doi.org/10.1007/s10706-019-01153-z.

Mahmood, Wael, and Ahmed Mohammed. "New vipulanandan pq model for particle size distribution and groutability limits for sandy soils." Journal of Testing and Evaluation 48, no. 5 (2020), https://doi.org/10.1520/JTE20180606.

Mahmood, Wael, Ahmed Mohammed, and Saman HamaHussein. "Predicting mechanical properties and ultimate shear strength of gypsum, limestone and sandstone rocks using Vipulanandan models." Geomechanics and Geoengineering (2019): 1-1, https://doi.org/10.1080/17486025.2019.16324 94.

Mohammed, Ahmed, and Wael Mahmood. "Statistical variations and new correlation models to predict the mechanical behavior and ultimate shear strength of gypsum rock." Open Engineering 8, no. 1 (2018): 213-226, DOI: https://doi.org/10.1515/eng-2018-0026.

Mohammed, Ahmed, and Wael Mahmood.

rr14322@auis.edu.krd, ahmed.salih@auis.edu.krd

${ }^{1}$ Corresponding author: Engineering Department, American University of Iraq, Sulaimani, Sulaimani - Kirkuk Rd, Sulaimania 
"Vipulanandan failure models to predict the tensile strength, compressive modulus, fracture toughness and ultimate shear strength of calcium rocks." International Journal of Geotechnical Engineering (2018): 1-11, https://doi.org/10.1080/19386362.2018.14686 63.

Nejad, F. M., Tolouei, M., Nazari, H., \& Naderan, A. (2018). Effects of Calcium Carbonate Nanoparticles and Fly Ash on Mechanical and Permeability Properties of Concrete. Advances in Civil Engineering Materials,7(1), 20180066. doi:10.1520/acem20180066

Nguyen, T. B., Chatchawan, R., Saengsoy, W., Tangtermsirikul, S., \& Sugiyama, T. (2019). Influences of different types of fly ash and confinement on performances of expansive mortars and concretes. Construction and Building Materials,209, 176-186. doi:10.1016/j.conbuildmat.2019.03.032

Omar,. (2015). Effect of Local Steel Slag as a Coarse Aggregate on Properties of Fly Ash BasedGeopolymer Concrete. International Journal of Civil, Environmental, Structural, Construction and Architectural Engineering,9(11).

Oner, A., \& Akyuz, S. (2007). An experimental study on optimum usage of GGBS for the compressive strength of concrete. Cement and Concrete Composites,29(6), 505-514. doi:10.1016/j.cemconcomp.2007.01.001

PATIL. (2015). To Study the Effect of Untreated Algae, Kitchen and Garage Wastewater on Strength Characteristics of Concrete as Curing Water's. International Research Journal of Engineering and Technology.

Pereira, P., Evangelista, L., \& Brito, J. D. (2012). The effect of superplasticisers on the workability and compressive strength of concrete made with fine recycled concrete aggregates. Construction and Building Materials,28(1), 722-729. doi:10.1016/j.conbuildmat.2011.10.050

Qadir, W., Ghafor, K., \& Mohammed, A. (2019). Characterizing and Modeling the Mechanical Properties of the Cement Mortar Modified with Fly Ash for Various Water-to-Cement Ratios and Curing Times. Advances in Civil Engineering,2019, $1-11$. doi: $10.1155 / 2019 / 7013908$

Sahoo, S., Das, B. B., \& Mustakim, S. (2017). Acid, Alkali, and Chloride Resistance of Concrete Composed of Low-Carbonated Fly Ash. Journal of Materials in Civil Engineering,29(3), 04016242. doi:10.1061/(asce)mt.1943-5533.0001759

Sathawane, S. H., Vairagade, V. S., \& Kene, K. S. (2013). Combine Effect of Rice Husk Ash and Fly Ash on Concrete by $30 \%$ Cement
Replacement. Procedia Engineering,51, 35-44. doi:10.1016/j.proeng.2013.01.009

Shaikh, F., \& Supit, S. (2015). Compressive strength and durability of high-volume fly ash concrete reinforced with calcium carbonate nanoparticles. Fillers and Reinforcements for Advanced Nanocomposites,275-307. doi:10.1016/b978-0-08-100079-3.00011-9

Siddique, R. (2011). Properties of self-compacting concrete containing class F fly ash. Materials \& Design,32(3), 1501-1507. doi:10.1016/j.matdes.2010.08.043

Song. (2005). Durability of fly ash based Geopolymer concrete against sulphuric acid attack. International Conference On Durability of Building Materials and Components.

Sorkor. (2014). Curing of concrete with wostewoter ond curing compounds : Effect on strength ond woter obsorption. The Indian Concrete Journal.

Torii, K., \& Kawamura, M. (1994). Effects of fly ash and silica fume on the resistance of mortar to sulfuric acid and sulfate attack. Cement and Concrete Research,24(2), 361-370. doi:10.1016/0008-8846(94)90063-9

Torii,, K. (1995). 95/06015 Sulfate resistance of high fly ash content concrete. Fuel and Energy Abstracts,36(6), 427. doi:10.1016/01406701(95)97664-6

Verma,. (2013). Influence of Aggressive Chemical Environment on High Volume Fly Ash Concrete. Concrete Research Letters.

Vipulanandan, C., and A. Mohammed. "Magnetic field strength and temperature effects on the behavior of oil well cement slurry modified with iron oxide nanoparticles and quantified with vipulanandan models." Journal of Testing and Evaluation 48, no. 6 (2020), https://doi.org/10.1520/JTE20180107.

Vipulanandan, C., \& Mohammed, A. (2020). Effect of drilling mud bentonite contents on the fluid loss and filter cake formation on a field clay soil formation compared to the API fluid loss method and characterized using Vipulanandan models. Journal of Petroleum Science and Engineering, 189, 107029.

Wang, H., Li, H., Liang, X., Zhou, H., Xie, N., \& Dai, Z. (2019). Investigation on the mechanical properties and environmental impacts of pervious concrete containing fly ash based on the cement-aggregate ratio. Construction and Building Materials,202, 387395. doi:10.1016/j.conbuildmat.2019.01.044

Zheng, X., Ji, T., Easa, S. M., \& Ye, Y. (2018). Evaluating feasibility of using sea water curing for green artificial reef concrete. Construction and Building Materials, 187, 545552. doi:10.1016/j.conbuildmat.2018.07.140 